\title{
The Discourse of Authenticity and Revitalization in Heritage Tourism
}

\section{Chinwe Chimezie Uwaoma}

Department of Archaeology and Tourism, Faculty of Arts, University of Nigeria Nsukka, Nsukka, Nigeria

Email address:

chimezie.uwaoma.pg03405@unn.edu.ng,chinwechimeziegj@gmail.com

\section{To cite this article:}

Chinwe Chimezie Uwaoma. The Discourse of Authenticity and Revitalization in Heritage Tourism. International Journal of Sustainable Development Research. Special Issue: Authenticity and Revitalizations as Vital Part in Sustainable Heritage Tourism Development. Vol. 6, No. 1, 2020, pp. 1-6. doi: 10.11648/j.jijsdr.20200601.11

Received: December 5, 2019; Accepted: December 31, 2019; Published: January 9, 2020

\begin{abstract}
Heritage Tourism is one of the fastest growing aspects of tourism wherein the tourist wants to have an experience which authentically represents a people's heritage such as their architectural design, folklores, festivals etc. However the underlying question is how this authenticity determined which the heritage tourist is looking for, since a lot of cultures and traditions are on the verge of extinction both in form and practice? Also most of the generation of people that originated these cultures is no longer alive. This article has looked at this trend in this article and has come up with ideas in which authenticity and revitalization in heritage tourism will be properly incorporated in heritage tourism. The reason for this is because in heritage tourism issues of authenticity and revitalization are continuously discussed and re-discussed in order to reappropriate tourism consumption. However, a lot scholars argue that the experience of most tourist are far from authentic, even though tourism is fundamentally a search for authenticity but in our modern world as argued by most scholars the experience is far from authentic due to the nature in which tourism is strategically contrived to meet the demands of modern tourists. It is argued that what these tourists have is "staged authenticity".
\end{abstract}

Keywords: Authenticity, Revitalization, Heritage and Tourism

\section{Introduction}

Heritage has various audiences one of them consisting of tourists. The members of these audiences all interpret heritage differently, depending on the social context within which it is produced and the manner in which it is presented. Hence the need for authenticity and revitalization is in the practice of heritage tourism. Revitalization is of great importance in the discourse of heritage tourism since it brings to bear the local context in which this heritage is situated for it to be properly revitalized.

As noted in this article UNESCO has already outlined criteria for judging authenticity which in my own opinion should be adopted by the various stakeholders in heritage tourism development of every country and community. The Nara document on authenticity should be a working document for every revitalization project embarked by heritage tourism stakeholders and practitioners.

Heritage tourism is based on the concept that each community has a story to tell. To the heritage tourist, the story must be that, that authentically talks about the culture, history, sites, customs and arts of a particular place, in this the heritage tourist has a personal encounter with traditions, history and culture. This therefore necessitates the emphasis on authenticity and revitalization.

\section{What Is Authenticity in Heritage Tourism}

Authenticity is a cultural and textual phenomenon that relies on the ability to utilize, recreate and project. [1]

Authenticity is the degree to which a historic site and its surrounding context convey information about the past honestly and accurately. Authenticity is a quality of great importance to cultural heritage tourism. The tourist seeks two basic types of authenticity:

1. Materials form (integrity) which is a tangible authenticity.

2. The quality of experience which is an intangible 
authenticity. Authenticity is integral with integrity.

According to UNESCO's definition of authenticity based on the Nara meeting of 1994 (Nara a city in Japan) which is commonly referred to as the Nara Document on authenticity. The definition goes thus, authenticity is a measure of how well attributes convey potential OUV (Outstanding universal value), [2] this is for heritages that are named as world heritage. These attributes for checking authenticity based on outstanding universal value include:

Form, design, materials, function, traditions, setting, languages and spirit. Authenticity can be compromised if the attributes are weak-communities cease to thrive, buildings collapse, traditions disappear and soon. In the case of archaeological sites, authenticity is judged according to the ability of the archaeological remains to truthfully convey their meaning. In many cases conjectural reconstruction might hinder this process and compromise authenticity. For each property the attributes that have been identified as conveying the potential OUV should be considered for the way that might be said to truthfully convey or express that value. For example, for an urban area it might be appropriate to consider structures, spatial plans, as well as traditions and socio-environmental structures of the living communities that populate the property and which allow it to express its value. In the Nara document authenticity is about the link between attributes and potential outstanding universal value [3]. That link needs to be truthfully expressed that the attributes can fully convey the value of the property. Outstanding universal value (OUV) means cultural and natural significance which is so exceptional as to transcend national boundaries and to be of common importance for present and future generations of all hu8manity. For a cultural or heritage site to be deemed outstanding universal value, a property must also meet the conditions of integrity and authenticity and must have an adequate protection and management system to ensure its safeguarding.

Table 1. The three pillars of outstanding universal value IUCN 2007.

\begin{tabular}{lll}
\hline $\begin{array}{l}\text { Property meets one } \\
\text { or more world }\end{array}$ & $\begin{array}{l}\text { Property meets } \\
\text { conditions of integrity }\end{array}$ & $\begin{array}{l}\text { Property meets the } \\
\text { requirements for protection } \\
\text { heritage criteria }\end{array}$ \\
\hline
\end{tabular}

A property is considered to be of OUV with the following 10 criteria's:
1. Represent a masterpiece of human creative genius.

2. Exhibit an important interchange of human values, over a span of time or within a cultural area of the world, on developments in architecture/technology, monumental arts town-planning or landscape design.

3. Bear a unique or at least exceptional testimony to a cultural tradition or to a civilization which is living or which has disappeared.

4. Be an outstanding example of a type of building, architectural or technological ensemble or landscape which illustrates:

5. Significant stages (s) in human history.

6. Be an outstanding example of a traditional human settlement, land use, or sea-use which is representative of a culture (cultures) or human interaction with the environment especially when it has become vulnerable under the impact of irreversible change.

7. Be directly or tangibly associated with events or living traditions with ideas, or with beliefs, with artistic and literary works of outstanding universal significance.

8. Contain superlative natural phenomena or areas of exceptional natural beauty and aesthetic importance.

9. Be outstanding examples representing major stages of earth's history, including the record of life, significant on-going geological processes in the development of landforms or significant geomorphic or physiographic features.

10.Be outstanding examples representing significant ongoing ecological and biological processes in the evaluation and development of terrestrial, freshwater coastal and marine ecosystems and communities of plants and animals.

11. Contain the most important and significant natural habitats for in-situ conservation of biological diversity, including those containing threatened species of OUV from the point of view of science or conservation.

Authenticity only applies to cultural properties and to the cultural aspects of "mixed" properties. A statement of authenticity needs to set out the ability of a property to convey its potential OUV through the way its attributes convey their value truthfully (UNESCO credibly, genuinely)[4] (Operational Guideline, PP 79-86. The attribute for assessing authenticity is analyzed further in this format:

Table 2. Authenticity Assessment.

a. Given that authenticity must be judged within the cultural context to which the property belongs what is that cultural context?
b. Does the attribute credibly and truthfully convey the potential outstanding universal value of the property?
c. Can the potential OUV be understood because the attributes are believable and honestly portray the value?
d. To what degree is the value present in or expressed by the attributes?
e. What were the original characteristics of the property's cultural heritage and how have these changed through time?
f. Have changes in the attributes reduced the ability to understand the value of the property?
g. Has the property been reconstructed to any degree? If so was this based on complete and detailed documentation? Was there
any conjecture used in the reconstruction? It is noted that reconstruction can sometimes be part of the value.
$\begin{array}{ll}\text { 1) Form and design } & \text { a. Has the form or design been changed and, if so, to what extent? It is noted that sometimes change is part of the value. } \\ \text { 2) Materials and } & \text { a. Has the materials, fabric or substance been changed or replaced? If so, to what extend? } \\ \text { substance } & \text { b. Have repairs been carried out using materials traditional to the culture? } \\ \text { 3) use and function } & \text { a. Who does the use or function relate to? } \\ \end{array}$




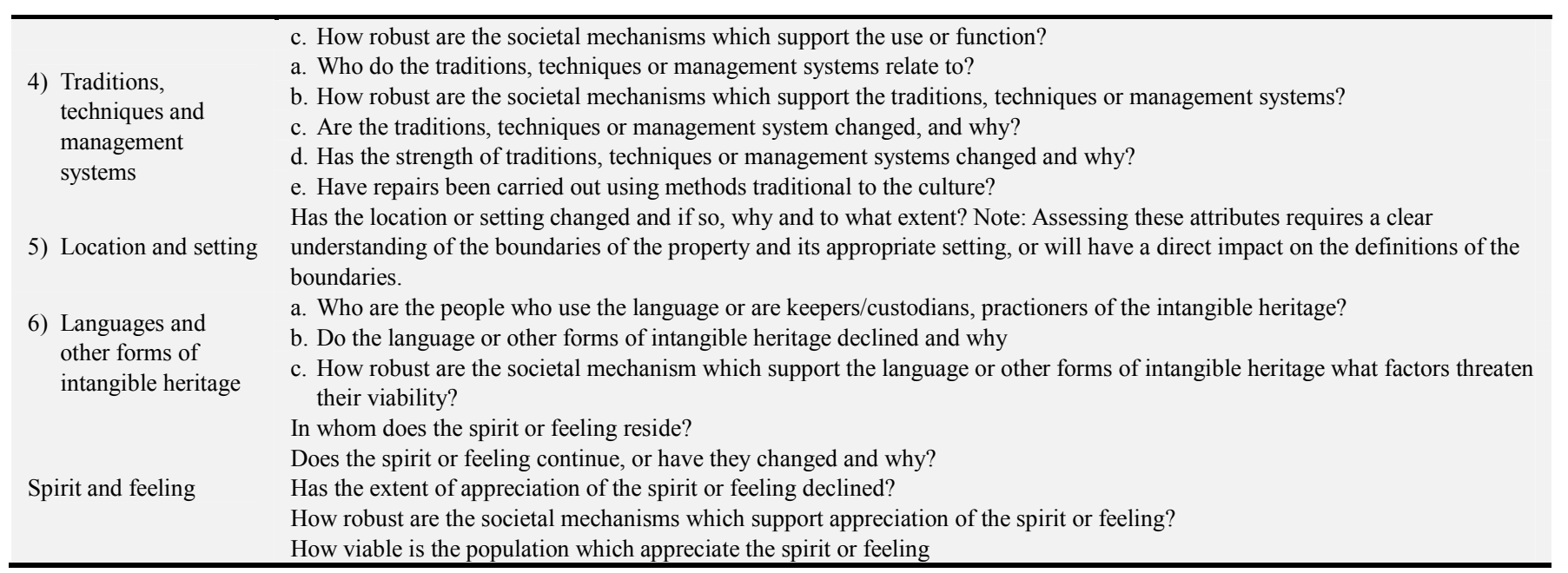

The discourse of authenticity in heritage tourisms is also looked at in these contexts

1. Objectivism

2. Constructivism

3. Existentialism

Objectivism: Is mainly based on the museum orientation of objects examined by an expert to determine their true nature [5]. It implies all that is genuine unadulterated without hypocrisy, honest and real [6].

However with the rise of postmodernism it is argued that there is no actual, true, genuine objective reality. This gave rise to constructive and existential authenticity in tourism. The constructivist states that things appear authentic not because they are inherently authentic, but because they are an "invention of tradition"[7] or constructed through negotiated meaning making interpretation and agreement [8]. They emphasize the pluralistic nature of the meaning making process through which authenticity, defined as "verisimilitude, geniuses, originality and authority, is established, recognized and projected unto an object by the influence of social discourse. [9-10]. In this sense, authenticity is a projection of tourists beliefs, expectation, preferences and stereotyped images unto toured objects [11]. These objects which can initially be "inauthentic" or artificial" as judged by experts may subsequently become "emergent authenticity" with the passage of time [12].

Wang breaks the conventional thought of toured-objects oriented authenticity and develops existential authenticity" to suggest a strong sense of "authentic self as a real feeling embedded in two categories.

The first category of "Intrapersonal authenticity relates to the bodily feelings of pleasure, relaxation, spontaneity and self making, not because the tourists find the toured objects, are authentic but simply because they are engaging in nonordinary activities free from the constraints of the daily life [11]. The second category lies in the interpersonal orientation of authenticity in which tourists are driven by a desire for cultural exchange with the "other" and intensely authentic, natural and emotional interaction between friends and family members or touristic communities [12].

Case study of Authenticity
Using the attributes stated by UNESCO in assessing authenticity for heritages listed for world Nomination [13]. The following is case study; these attributes as applied to the "Tombs Buganda Kings at Kasubi (Uganda) [14].

1. Form and design: The spatial organization of the tombs represents, the best example of a Buganda palace architectural design.

2. Materials and substance: The four royal tombs within the Muzibu Azaala Mpanga, the main building and use of materials-consists of wood, thatch, reed, wattle and daub.

3. Use and function: it is a major spiritual center for the Buganda and is the most active religious site in the kingdom-including cultural religious practices and rituals.

4. Traditions, techniques and management systems: The site continues to be managed in a traditional manner through a complex system or responsibilities. Traditions-cultural/religious practices and rituals.

5. Location and setting: The tomb is at the original location and surviving rural setting-including the agricultural part of the site which continues to be farmed in a traditional manner.

6. Languages and other forms of intangible heritage Religious: It is a major centre for the Buganda and is the most active religious site in the kingdom, including a place where the Kabaka and his representative carry out important rituals relating to Buganda culture.

7. Spirit and feeling: The built and natural elements of the kasubi tombs site are charged with historical, traditional and spiritual values.

Case Study on Authenticity of Museum Objects Ancient Jewelry in Museum

In a work carried out by Megan Cifarelli on adornment, identity, and authenticity of ancient jewelries AJA. She stated that while most of these objects entered collections legally, and may in fact be genuine, without archaeological documentation, it is simply not possible to confirm their authenticity beyond a doubt [15]. This lack of contextual information and assurance of authenticity does not eliminate, but does curtail, the interpretative potential of the jewelries. 
She further states that in the absence of contextual information of these collections visitors admiring ancient jewelry in museum can only respond to its aesthetic qualities and to the allure of valuable materials and technical virtuosity-the very attributes that attract shoppers in jewelry store' the review which focused on the "Museum of natural history in Chicago made the following discoveries that there is no distinction between the objects that are excavated and those that are not excavated. She also mentioned that the Chicago exhibition which was beautifully designed and grouped into six, five of these groups are either cultural or regional. Mesopotamian, Levantine, Persian, Egyptian and Islamic. However, the Mesopotamian case is both a highlight of the exhibition and also a disappointment, this is because visitors did not know that the Jewelries on display are from the excavations of the third millennium B. C. E. centuries at Kish, this is because the case and object labels did not mention the site Kish, nor do they specify which objects come from excavations. It only mentioned that the object came from Iraq. This speaks against the authenticity of the object.

\section{Revitalization}

Revitalization, as Wallace Anthony F. C. describes it, is a model for understanding culture change, brought about by significant and often complex environmental, economic, social, cultural and psychological stresses in the host society, which have been caused by new or intensified contact with an outside society [16]. It is often fueled by visionary local leaders who perceiving the culture as once functional but now operating unsatisfactorily, are desirous of a restoration of ideal cultural values.

The difference between revitalization and development is found in the agentive role of the local individual revitalization of a culture is found in the local individual while that of development is exclusively in the hands of outsiders [17]. A revitalization movement is fueled by locals responding to pressures on an individually experienced, yet collectively mediated conception of a group's cultural existence. The revitalization paradigm emphasizes the many process that impels locals to make significant changes to their society by calling upon, yet re-inventing their narratively understood' identify. The revitalization model brings local hosts into a direct and more equal relationship with tourist guests as well as with the variety of other actors operating within the field of touristic production. A revitalization paradigm allows for greater attention to be paid to the significance of locals' discourses and practices in relationship to the panoply of others within the field of touristic production. This is especially significant for postcolonial states who struggle to define and represent themselves on a newly enlarged, global stage [18].

An example of a city revitalized for tourism purposes is Hoi An a city in Viet-Nam. Hoi An was initially seen as 'old Ha Noi a name given to it by the first tourists who arrived the town in the 1980's having looked at the stunning outward ossification of the town' [18].

However, the town was revitalized as it began to be seen as a tourism destination site. The actual transformation of the town/city was not influenced merely by a standardized development plan but rather a unique set of conjectures between outsiders and some visionary locals (such as kazimier Kwiatkow ski popularly known as Kazim) who represented the town not as a stagnant and economically inefficient place, but a heritage site worthy of visitation. One of the ways in the city town was revitalized by the locals was through their "Lantern festival" an invented tradition designed to portray an Idealized vision of Hoi An's past. This is held on the $15^{\text {th }}$ day of every lunar month. It was intended to bring back a night in the old days. During this festival artifacts of modernity are removed florescent lights are turned off, public spaces are then lighted with strings of traditional styled paper lanterns lining the streets. Motor cycles and bicycles are prohibited from entering the city center. To maintain its $18^{\text {th }}$ century air, television watching in private is strictly prohibited, since it casts an artificial glow. The lantern festival was designed not solely for economic purposes but also as an educational tool for Vietnamese outside of the town. Throughout the rest of the lunar month the people are at liberty to move forward with modernity but once a month there is a kind of a check to this so-perceived progress where all this must be denied under the flow of the lantern light, the ideal state is restored once again.

Another case study of revitalization is the historic town of Kota Tua the heart of Jakarta Indonesia. Kota Tua contains a variety of cultural heritage sites, which included buildings, canals constructed during the $17^{\text {th }}$ and $18^{\text {th }}$ century which attract tourists [19]. The town faced numerous challenges despite its cultural heritage, these challenges ranged from inadequate infrastructures, economic challenges, to the demolition and deterioration of historic buildings. The first revitalization program of the town was established in 1974 which was aimed at protecting heritage sites and developing the area as a tourist attraction. Further concrete measures on the revitalization of Kota Tua began in 2004 with a Master Plan which contained guidelines on the revitalization of the town. In 2006, the process began, then in 2014 the Master Plan was passed into law via Decree No. 36/2014. In the revitalization program that began, Taman Fatalillah square was restructured. Improvement of public spaces, pedestrian access and transportation and relocation of the city's street vendors are among other things.

Also the Government of the Special Capital Region of Jakarta with collaboration from other stakeholders worked to apply for UNESCO World Cultural Heritage Status. This application was made with the belief that it would accelerate the revitalization process of the town and also attract both domestic and international tourists. Recommendations were also made that would boost the revitalization of the town. This would necessitate physical and nonphysical changes. The recommendation was organized into three categories:

1. Immediate Action.

2. Medium-term Action. 


\section{Long-term Vision.}

Immediate action involved accessibility for visitors by promoting the use of public transport. Pedestrian comfort was also prioritized. Creation of cultural events was also part of the immediate actions such as festivals, night bazaars etc. Intermediate action involved improvement of public spaces and the overall urban landscape of Kota Tua. To improve the "adaptive reuse" of historic buildings was also an intermediate action recommended for the revitalization of the town. The long- term vision was human oriented urban environment with the conservation of heritage buildings and artefacts.

The non- physical aspect of the recommendation was related to building institutional frameworks which included regulation, providing political support and finance. At this non physical aspect, the recommendation was also grouped into immediate actions, intermediate actions and long-term vision. Immediate actions involved considering cultural heritage sites as part of the city's nations identity, boost the political will and establish leadership support, enhance coordination between national and local government institutions and also improve capacity in human resources.

For intermediate actions a re- definition of the boundary of heritage city has to be established by differentiating between the 'core area' which will be the main target for UNESCO and a larger "buffer area" which will include four of the thousand islands. Also an integrated revitalization plan that will consider strengthening existing institutional framework was also part of intermediate actions. Finally, the long- term vision was ensuring that Kota Tua and the administered heritage area remained socioculturally and economically vibrant and also conserved.

\section{Conclusion}

The presence of a heritage stimulated only by its materials aspect leads to a revitalization that can be identical, a replica of the historical form, but that will no longer be the authentic one because it no longer has the relationship linked with creative process that engendered it as a product of its time, instead it will have become a work for the future, following the construction's historical knowledge, with materials and techniques of the present, which of course, will express a vision more of the future, than of the past. Also the contemporary heritage field is marked by a number of intersecting theories often reexamining long -inherited ideas, cultural dynamics, political issues and challenges of governance and policy [20].

Authenticity and revitalization in heritage tourism should in corporate the UNESCO's attributes for assessing authenticity not just for World heritage sites but for all sites and all heritage both tangible and intangible. These attributes which are form and design, materials and substance, use and function, traditions, techniques and management systems, location and setting, language and other forms of intangible heritage, spirit, and feeling. If these attributes are incorporated in any revitalization program it will go a long way in making sure that what is presented to the tourist is authentic. Having reviewed what authenticity and revitalization is with case studies supporting them it is therefore of necessity that they be not neglected in promotion and development of a sustainable heritage tourism.

The reason for this, is because heritage has multiple values which are: cultural value, aesthetic value, environmental value, symbolic value and social value [19]. Hence, the discourse of authenticity and revitalization in heritage tourism cannot be over emphasized.

\section{Acknowledgements}

This is part of a series of seminars presented for the award of a $\mathrm{PhD}$ in the department of Archaeology and Tourism, University of Nigeria Nsukka. 2017/2018 -2019/2020 academic sessions.

\section{References}

[1] Graham. C. (2001) 'Blame it on Maureen O' hara': Ireland and the trope of authenticity, Cultural Studies 15 (1) 58-75.

[2] UNESCO World heritage centre (2005) Vienna Memorandum on world heritage and contemporary Architecture managing the Historic Urban Landscape.

[3] UNSECO world heritage centre (1994) Nara Document on Authenticity http://www.International.ICOMOS.Org/charters/nara-e.htm.

[4] UNEP-WCMC (2004) Review of the world heritage network. Biogeography, habitats and Biodiversity. Cambridge, UK, UNEP World Conservation Monitoring centre.

[5] Leite, N. \& Graburn, N. (2009) Anthropological interventions in tourism studies. The SAGE handbook of tourism studies pp $35-64$

[6] Relph, E. (1976). Place and placeness London Pion.

[7] Hisbawn. E. \& Ranger. T. (1983). The invention of tradition. Cambridge. Cambridge university press.

[8] Hughes, G. (1995). Authenticity in tourism Annals of tourism research 22 (4) 781-803.

[9] Branner, E. M. (1994) Abraham Lincoln as authentic reproduction: A critique of postmodernism. American anthropologist 96 (2) 349-415.

[10] Belhassen. Y. (et al (2008) the search for authenticity in the pilgrims experience. Annals of tourism research 35 (3), 668-689.

[11] Wang, N. (1999) Rethinking authenticity in tourism experience. Annals of tourism Research, 26 (2) 349-370.

[12] Cohen. E. (1988) authenticity and commoditization in tourism. Annals of tourism research. 15 (3), 391-386.

[13] Hillary, A. kokkonen, M and Max, (eds). 2003 proceedings of the world heritage marine Biodiversity workshop. Paris, UNESCO. World heritage centre (world heritage papers 4.).

[14] Duncan Marshall (Cord. Author) (2011) preparing world heritage Nominations second Edition. UNESCO. 61-65. 
[15] Megan Cifarelli (2010) "Adornment, Identity and Authenticity: Ancient Jewelry in and out of context". American Journal of Archaeology online Museum Review.

[16] Wallace Anthony. F. C. (1956) Revitalization Movements. American Anthropologist Volume 58 (2).

[17] Ferguson James (1994) Anti Politics Machine: Development and Bureaucratic Power in Lesotho. University of Minnesota Press. London.

[18] Michael. A. Di Giovien (2009) "Revitalization and counter- revitalization: Tourism, heritage and the Lantern festival as catalysts for regeneration in Hoi An, Vietnam" Journal of policy research in tourism, Leisure and Event Voit 1 (3) 208230 .

[19] UCLG Peer Learning (2017) "Revitalizing cultural heritage: a compre Comprehensive urban plan to revitalize Kota Tua in Jakarta" Jakarta Indonesia.

[20] Erica Avrami et al (2019) Values in Heritage Management (Emerging Approaches and Research Directions). The Getty Conservation Institute, Los Angeles. 